\title{
Signifikansi Paradigma Pendidikan Kritis dalam Dunia Posrealitas
}

\author{
Gianto \\ Sekolah Tinggi Agama Isam Negeri Samarinda
}

\begin{abstract}
New world as a result of the development of science and technology mutakhir makes sign no longer reflect reality. Representation is no longer associated with the truth. The new world was built by various forms of distortion of reality, free game mark, meaning irregularities and artificiality meaning. The new world was built by many reality distortions, the free sign game, the deviation and appearance of meaning. A new reality world draws a metamorphosis which is got by human, from what mentioned as a reality condition, turn to post-reality. The post-reality will not effect at all to human if the critical awareness of human is kept on. Yet, if the critical awareness of human has been eroded, the human has artificial awareness. Actually, the post-reality is not a threat for human's life if the critical awareness is kept on. Yet, if the critical awareness of human is eroded, human will be pressed and dominated by post-reality world.
\end{abstract}

Keywords: critical education, posreality

\begin{abstract}
Abstrak
Dunia baru akibat dari perkembangan ilmu pengetahuan dan teknologi mutakhir menjadikan tanda tidak lagi merefleksikan realitas. Representasi tidak lagi berkaitan dengan kebenaran. Dunia baru itu dibangun oleh berbagai bentuk distorsi realitas, permainan bebas tanda, penyimpangan makna dan kesemuan makna. Dunia realitas baru tersebut melukiskan sebuah metamorfosis yang dialami oleh manusia, dari apa yang disebut sebagai kondisi realitas, ke arah apa yang disebut sebagai kondisi posrealitas (post-reality). Realitas dunia posrealitas tersebut tidak akan berdampak apa-apa terhadap manusia jika fakultas kesadaran kritis manusia tetap terjaga, akan tetapi jika fakultas kritis manusia telah terdegradasi maka yang akan terjadi adalah manusia yang berkesadaran artifisial. Sebenarnya posrealitas bukanlah sebuah ancaman bagi kehidupan manusia sejauh fakultas kritis manusia masih terjaga dengan baik, akan tetapi jika fakultas kritis manusia telah terdegradasi maka yang terjadi adalah manusia yang tertindas dan terdominasi oleh dunia posrealitas.
\end{abstract}

Kata Kunci: pendidikan kritis, posrealitas 


\section{A. Pendahuluan}

Waktu berubah, dan kita (ikut) berubah juga di dalamnya. Waktu berubah dan cara-cara manusia mengekspresikan dirinya, menelusuri jejak pencarian makna tentang siapakah dirinya bersama orang lain (masyarakat) juga berubah. Jika dikatakan bahwa tidak ada yang tetap di dunia ini mungkin yang tetap hanyalah perubahan itu sendiri. ${ }^{1}$

Ada sebuah perubahan besar yang terjadi pada awal Milenium ketiga, yaitu terbentuknya sebuah dunia baru sebagai akibat dari perkembangan ilmu pengetahuan dan teknologi mutakhir, yang di dalamnya tercipta berbagai definisi dan pemahaman baru mengenai apa yang disebut realitas. ${ }^{2}$ Perubahan konsep-konsep yang terjadi memunculkan kesadaran bahwa kesadaran diri itu sendiri adalah bentukan manusia juga. Dengan kata lain, orang semakin waspada akan aspek formatif maupun ideologis dari kesadaran tersebut. sedangkan di sisi lain, batas antara dunia imajinasi atau dunia artifisial dan dunia riil justru semakin kabur. Di sini kita mulai bertemu dengan rupa-rupa paradoks antara konsep dan realitas. ${ }^{3}$ Di dalam relasi baru realitas tersebut, tanda tidak lagi merefleksikan realitas; ${ }^{4}$ representasi tidak lagi berkaitan dengan kebenaran seperti dikemukakan oleh H.A.R. Tilaar dalam

${ }^{1}$ Mudji Sutrisno \& Hendar Purwanto, Teori-Teori Kebudayaan, (Yogyakarta: Kanisius, 2005), hlm. 7.

${ }^{2}$ Reality. The quality of being real or of resembling sth that is real: the lifelike reality of his paintings. Lihat, A S Hornby, Oxford Advanced Leaner's Dictionary, (New York: Oxford University Press, 1995), hlm. 969.

${ }^{3}$ Gading J. Sianipar, "Tubuh dan Kesadaran dalam Budaya Imajinasi: Penafsiran atas Budaya Masyarakat yang Diserbu Oleh Teknologi dan Media Komunikasi”, Teori-Teori Kebudayaan,(Yogyakarta: Kanisius, 2005), hlm. 300-301.

4 Tanda adalah segala sesuatu - warna, isyarat, kedipan mata, objek, rumus matematika, dan lain-lain - yang merepresentasikan sesuatu yang lain selain dirinya. Hal yang dirujuk oleh tanda, secara logis, dikenal sebagai referen (objek atau petanda). Ada dua jenis referen: (1) referen kongkrit, seperti binatang yang dirujuk oleh kata cat, dan (2) referen abstrak, seperti konsep "ide cemerlang" yang dirujuk oleh figur bola lampu yang menyala di atas. Referen konkrit adalah sesuatu yang dapat ditunjukkan hadir di dunia nyata. Referen abstrak bersifat imajiner dan tidak dapat diindikasikan hanya dengan menunjukkan pada suatu benda. Tanda mengantarai persepsi. Lihat, Marcel Danesi, Pesan, Tanda dan Makna Buku Teks Dasar Mengenai Semiotika dan Teori Komunikasi, terj. Evi Setyarini dan Lusi Lian Piantari, (Yogyakarta: Jalasutra, 2011), hlm. 6-7. 
Perubahan Sosial dan Pendidikan: Pengantar Pedagogik Transformatif untuk Indonesia; informasi tidak lagi mengandung objektivitas pengetahuan. Dunia baru itu, sebaliknya, adalah dibangun oleh berbagai bentuk distorsi realitas, permainan bebas tanda, penyimpangan makna dan kesemuan makna. ${ }^{5}$

Dunia realitas baru tersebut melukiskan sebuah metamorfosis yang dialami oleh manusia, dari apa yang disebut sebagai kondisi realitas, ke arah apa yang disebut sebagai kondisi posrealitas (post-reality). Menurut Jean Baudrillard, posrealitas (hiperrealitas) adalah gejala bermunculannya berbagai realitas buatan yang bahkan lebih real daripada yang real. Bukan hanya lebih real, posrealitas juga lebih ideal ataupun lebih baik dari yang aslinya. ${ }^{6}$ Kondisi posrealitas adalah sebuah kondisi, yang di dalamnya prinsip-prinsip realitas itu sendiri telah dilampaui, dalam pengertian diambil alih oleh substitusi-substitusinya, yang diciptakan secara artifisial lewat bantuan ilmu pengetahuan, teknologi dan seni mutakhir, yang menghancurkan asumsi-asumsi konvensional tentang apa yang disebut yang nyata (the real). Selain itu, menurut Yasraf Amir Piliang, posrealitas adalah keadaan runtuhnya realitas, yang diambil oleh raksasa modelmodel (citraan, halusinasi, simulasi), yang dianggap lebih nyata dari realitas sendiri, sehingga perbedaan keduanya menjadi kabur. ${ }^{7}$

\section{B. Metode penelitian}

Secara sederhana metode penelitian dapat diartikan sebagai cara ilmiah untuk mendapatkan data dengan tujuan dan kegunaan tertentu. ${ }^{8}$ Dengan demikian, maka langkah-langkah yang akan ditempuh oleh peneliti dalam menggali dan menginterpretasikan data guna menemukan jawaban permasalahan yang diangkat dalam penelitian ini meliputi langkah-langkah berikut:

${ }^{5}$ H.A.R. Tilaar, Perubahan Sosial dan Pendidikan: Pengantar Pedagogik Transformatif untuk Indonesia, (Jakarta: Rineka Cipta, 2012), hlm. 57.

6 Jean Baudrillard, The Illusion of the End, (London: Polity Press, 1994), hlm. 6.

${ }^{7}$ Yasraf Amir Piliang, Sebuah Dunia yang Dilipat: Realitas Kebudayaan Menjelang Milenium Ketiga dan Matinya Posmodernisme, (Bandung: Mizan, 1998), hlm. 16

8 Sugiono, Metode Penelitian Pendidikan; Pendekatan Kuantitatif, Kualitatif dan RD, (Bandung: Alfabeta, 2006), hlm. 3. 
1. Jenis Penelitian. Penelitian ini merupakan jenis penelitian kepustakaan (library research). ${ }^{9}$ Artinya penelitian ini dilakukan melalui penelusuran dan telaah karya-karya ilmiah, yang tertuang dalam buku, majalah, jurnal, makalah, serta berbagai media yang mengulas tentang Konsep Dunia Posrealitas dan konsep atau Paradigma Pendidikan Kritis.

2. Pendekatan Penelitian. Adapun pendekatan yang digunakan dalam penelitian ini adalah pendekatan filosofis. Pendekatan filosofis digunakan untuk melihat secara mendalam tentang objek material seperti halnya nilai, prinsip-prinsip, tujuan dan konsep Dunia Posrealitas untuk kemudian dikaitkan dengan konsep atau Paradigma Pendidikan Kritis.

3. Teknik Pengumpulan Data. Teknik pengumpulan data adalah cara-cara yang dapat digunakan oleh peneliti untuk mengumpulkan data. "Cara" menunjuk pada sesuatu yang abstrak, tidak dapat diwujudkan dalam benda yang kasat mata, tetapi hanya dapat dipertontonkan penggunaannya. ${ }^{10}$ Untuk memperoleh data yang sesuai dengan penelitian ini, teknik pengumpulan datanya adalah dokumentasi. Dokumentasi adalah informasi yang di dokumentasikan dalam rekaman baik gambar atau foto, suara, tulisan atau manuskrip, atau yang lainnya. ${ }^{11}$ Penggunaan dokumentasi didasarkan pada alasan: Pertama, sumber ini tersedia dan siap pakai. Kedua, dokumentasi merupakan sumber informasi yang stabil, akurat, dan dapat dianalisis kembali. Ketiga, dokumentasi merupakan sumber informasi yang secara kontekstual relevan dan mendasar dalam penelitian. Keempat, sumber dokumen ini merupakan pernyataan legal yang dapat memenuhi akuntabilitas. Kelima, sumber ini bersifat non reaktif, sehingga tidak sukar ditemukan dengan teknik kajian. Penerapan teknik dokumentasi ini diarahkan kepada karya-karya Dunia Posrealitas dan Paradigma Pendidikan Kritis

4. Teknik Analisis Data. Setelah data-data yang terkait dengan Dunia Posrealitas dan Paradigma Pendidikan Kritis dalam

${ }^{9}$ Anton Bakker dan Ahmad Charis Zubair, Metodologi Penulisan Filsafat, (Yogyakarta: Kanisius, 1990), hlm. 63.

${ }^{10}$ Suharsimi Arikunto, Manajemen Penelitian, (Jakarta: Rineka Cipta, 2005), hlm. 100.

11 Kartini Kartono, Pengantar Metodologi Riset Sosial, (Bandung: Mandar Maju, 1990), hlm. 65. 
penelitian ini terkumpul melalui teknik pengumpulan data diatas, selanjutnya data tersebut dianalisis dengan metode conten analysis. Conten analysis merupakan metode yang digunakan untuk mengungkapkan isi sebuah buku dan pemikiran seseorang yang menggambarkan situasi penulis pada masyarakatnya pada saat buku itu ditulis atau pemikiran tersebut digulirkan. ${ }^{12}$ Kemudian langkah terakhir dari analisis datanya adalah menarik kesimpulan dari analisis yang telah dilakukan.

\section{Kerangka Teori}

Dalam perspektif pendidikan kritis, kegiatan pendidikan adalah melakukan refleksi kritis terhadap "the dominant ideology" ke arah transformasi sosial. Tugas utama pendidikan adalah menciptakan ruang agar sikap kritis terhadap sistem dan struktur ketidakadilan, serta melakukan dekonstruksi dan advokasi menuju sistem sosial yang lebih adil. Pendidikan tidak mungkin dan tidak bisa bersikap netral, bersikap objektif maupun berjarak dengan masyarakat (detachment) seperti anjuran positivisme. Visi pendidikan adalah melakukan kritik terhadap sistem dominan sebagai pemihakan terhadap rakyat kecil dan yang tertindas untuk menciptakan sistem sosial baru dan lebih adil. Dalam perspektif kritis, pendidikan harus mampu menciptakan ruang untuk mengidentifikasi dan menganalisis secara bebas dan kritis untuk transformasi sosial. Dengan kata lain tugas utama pendidikan adalah "memanusiakan" kembali manusia yang mengalami dehumanisasi karena sistem dan struktur yang tidak adil. ${ }^{13}$

Pemanusiaan, menurut pandangan aksiologis selalu menjadi problema pokok manusia, dan kini persoalan itu harus dipedulikan sungguh-sungguh. Kepedulian terhadap pemanusiaan seketika membawa kita pada pengakuan terhadap dehumanisasi, yang bukan hanya kemungkinan ontologis melainkan sudah menjadi kenyataan historis. Dalam sejarah, dalam konteks-konteks nyata serta objektif, pemanusiaan maupun dehumanisasi merupakan kemungkinan-kemungkinan bagi manusia sebagai makhluk yang

${ }^{12}$ Imam Prayogo, Metodologi Penelitian Sosial dan Agama (Bandung: Rosda Karya, 2003), hal. 71-73.

13 Mansour Faqih, "Pengantar Ideologi-Ideologi Pendidikan", Ideologi..., hlm. Evi. 
belum utuh, yang sadar akan ketidak-utuhan dirinya. Meski keduanya merupakan alternatif, hanya pemanusiaan yang menjadi fitrah manusia. Fitrah ini selalu diinjak-injak, namun justru tiap kali diinjak ia makin diteguhkan. Ia dikerdilkan lewat ketidakadilan, eksploitasi, penindasan dan kekerasan yang dilakukan oleh penindas melalui sistem yang tidak berkeadilan; ia diteguhkan kembali melalui dambaan kaum tertindas akan kebebasan dan keadilan, serta dikuatkan kembali lewat perjuangan kaum tertindas untuk memulihkan kembali kemanusiaan mereka yang telah hilang. 14

Freire seperti dikutip Mansour Fakih, menggolongkan kesadaran manusia menjadi: kesadaran magis (magical consciousness), kesadaran naif (naival consciousness) dan kesadaran kritis (critical consciousness). Yang dimaksud kesadaran magis yakni tingkat kesadaran yang tidak mampu mengetahui kaitan antara satu faktor dan faktor lainnya. Misalnya saja masyarakat miskin yang tidak mampu melihat kaitan kemiskinan mereka dengan sistem politik dan kebudayaan. Kesadaran magis lebih melihat faktor di luar manusia (natural maupun supra natural) sebagai penyebab ketakberdayaan. Proses pendidikan yang menggunakan logika ini tidak memberikan kemampuan analisis, kaitan antara sistem dan struktur terhadap satu permasalahan masyarakat. Murid secara dogmatik menerima "kebenaran" dari guru, tanpa ada mekanisme untuk memahami "makna" ideologi dari setiap konsepsi atas kehidupan masyarakat. ${ }^{15}$

Yang kedua adalah kesadaran naif. Keadaan yang dikategorikan dalam kesadaran ini adalah melihat "aspek manusia" menjadi akar penyebab masalah masyarakat. Dalam kesadaran ini, masalah etika, kreativitas, "need for achevement" dianggap sebagai penentu perubahan sosial. Jadi dalam menganalisis mengapa suatu masyarakat miskin, bagi mereka disebabkan karena "salah" masyarakat sendiri, yakni mereka malas, tidak memiliki jiwa kewiraswastaan, atau tidak memiliki budaya "membangun" dan seterusnya. Oleh karena itu "man power development" adalah

${ }^{14}$ Paulo Freire, Menggugat Pendidikan fundamentalisme, Konservatif, liberal, Anarkis: "Pendidikan yang Membebaskan, Pendidikan yang Memanusiakan", (Yogyakarta: Pustaka Pelajar, 2009), hlm. 434-435.

15 Mansour Faqih, "Pengantar Ideologi-Ideologi Pendidikan", Ideologi..., hlm. xvii 
sesuatu yang diharapkan akan menjadi pemicu perubahan. Pendidikan dalam konteks ini juga tidak mempertanyakan sistem dan struktur, bahkan sistem dan struktur yang ada adalah sudah baik dan benar, merupakan faktor "given" dan oleh sebab itu tidak perlu dipertanyakan. Tugas pendidikan adalah bagaimana membuat dan mengarahkan agar murid bisa masuk beradaptasi dengan sistem yang sudah benar tersebut. ${ }^{16}$

Kesadaran ketiga disebut sebagai kesadaran kritis. Kesadaran ini lebih melihat sistem dan struktur sebagai sumber masalah. Pendekatan struktur menghindari "blaming the victims" dan lebih menganalisis untuk secara kritis menyadari struktur dan sistem sosial, politik, ekonomi dan budaya dan akibatnya pada keadaan masyarakat. Paradigma kritis dalam pendidikan, melatih murid untuk mampu mengidentifikasi "ketidakadilan" dalam sistem dan struktur yang ada, kemudian mampu melakukan analisis bagaimana sistem dan struktur itu bekerja, serta bagaimana mentransformasikannya. Tugas pendidikan dalam paradigma kritis adalah menciptakan ruang dan kesempatan agar peserta pendidikan terlibat dalam suatu proses penciptaan struktur yang secara fundamental baru dan lebih baik. ${ }^{17}$

Skema Kategori Pengkodean Conscientizacao ${ }^{18}$

\begin{tabular}{|c|c|c|c|}
\hline & $\begin{array}{l}\text { Kesadaran Magis } \\
\text { "Menyesuaikan" }\end{array}$ & $\begin{array}{l}\text { Kesadaran Naif } \\
\text { "Memperbaharui" }\end{array}$ & $\begin{array}{l}\text { Kesadaran Kritis } \\
\text { "Mengubah" }\end{array}$ \\
\hline \multirow[t]{2}{*}{$\begin{array}{l}\text { I. PENAMAAN } \\
\text { Apa } \\
\text { masalahnya? } \\
\text { Apakah } \\
\text { seharusnya } \\
\text { Memang } \\
\text { demikian } \\
\text { adanya? }\end{array}$} & $\begin{array}{l}\text { 1. Penolakan terha-dap } \\
\text { Masalah: } \\
\text { a. Menolak tegas } \\
\text { b. Menghindari } \\
\text { masalah }\end{array}$ & $\begin{array}{l}\text { 1. Penyimpangan } \\
\text { Individu Penindas: } \\
\text { a. Individu-individu } \\
\text { tertindas tidak suka } \\
\text { pada penindas } \\
\text { b. b. Individu tertindas } \\
\text { tidak memenuhi } \\
\text { keinginan penindas } \\
\text { c. Agresivitas } \\
\text { Horisontal (intra- } \\
\text { punitive) }\end{array}$ & $\begin{array}{l}\text { 1. Menolak Penindas/ } \\
\text { Penegasan Diri: } \\
\text { a. Menolak untuk } \\
\text { meniru penindas } \\
\text { b. Memelihara etnisitas } \\
\text { c. Menegaskan } \\
\text { keunikan }\end{array}$ \\
\hline & $\begin{array}{l}\text { 2. Masalah Bertahan } \\
\text { Hidup: } \\
\text { a. Kesehatan buruk } \\
\text { b. Kemiskinan } \\
\text { c. Pengangguran } \\
\text { d. Pekerjaan yang tidak } \\
\text { mencukupi }\end{array}$ & $\begin{array}{l}\text { 2. Penyimpangan individu } \\
\text { penindas: } \\
\text { a. Penindas melanggar } \\
\text { hukum } \\
\text { b. Penindas melanggar } \\
\text { norma }\end{array}$ & $\begin{array}{l}\text { 2. Mengubah Sistem: } \\
\text { a. Prosedur, } \\
\text { masyarakat } \\
\text { b. Menolak sistem } \\
\text { yang menindas }\end{array}$ \\
\hline
\end{tabular}

${ }^{16}$ Faqih, "Pengantar Ideologi..., hlm. xvii.

${ }^{17}$ Faqih, "Pengantar Ideologi..., hlm. xvii.

${ }^{18}$ William A. Smith, Conscientizacao Tujuan Pendidikan Paulo Freire, (Yogyakarta: Pustaka Pelajar, 2008), hlm. 55-57 
e. Uang habis dengan sendirinya

\begin{tabular}{|c|c|c|c|}
\hline \multirow[t]{2}{*}{$\begin{array}{l}\text { II.BERFIKIR } \\
\text { Mengapa } \\
\text { keadaannya } \\
\text { demikian? } \\
\text { Siapa/ apa } \\
\text { yang salah? } \\
\text { Apa peran } \\
\text { anda dalam } \\
\text { keadaan } \\
\text { seperti ini? }\end{array}$} & & & \\
\hline & $\begin{array}{l}\text { 1. Fakta yang diserahkan } \\
\text { pada penguasa: } \\
\text { a. Faktor-faktor yang } \\
\text { tak terkendali: } \\
\text { b. Tuhan, nasib, } \\
\text { keberuntunganusia } \\
\text { dan seterusnya } \\
\text { c. Penindas selalu } \\
\text { menjadi pemenang } \\
\text { terhadap penindas }\end{array}$ & $\begin{array}{l}\text { 1. Tunduk pada Ideologi } \\
\text { Penindas: } \\
\text { a. Menerima } \\
\text { penjelasan atau } \\
\text { keinginan penindas } \\
\text { b. Konflik dengan } \\
\text { sesama } \\
\text { c. Menyalahkan nenek- } \\
\text { moyang } \\
\text { d. Kasihan pada diri } \\
\text { sendiri } \\
\\
\\
\\
\text { 2. Mengetahui bagaiman } \\
\text { penindas melanggar } \\
\text { norma: } \\
\text { a. Mengetahui maksud } \\
\text { penindas } \\
\text { b. Mengetahui } \\
\text { hubungan antara } \\
\text { penindas atau agen- } \\
\text { agennya } \\
\text { c. Mengeneralisasikan } \\
\text { satu penindas pada } \\
\text { semuanya } \\
\end{array}$ & $\begin{array}{l}\text { Mengetahui/Menolak } \\
\text { Ideologi Penindas dan } \\
\text { Kolusi: } \\
\text { a. Simpati/memahami } \\
\text { sesama } \\
\text { b. Mengritik } \\
\text { diri/mengetahui } \\
\text { perbedaan antara aksi } \\
\text { dan tujuan kritis } \\
\text { c. Menolak agresi } \\
\text { horisontal } \\
\text { d. Mengetahui jalannya } \\
\text { penindasan/korban } \\
\text { sistem } \\
\text { e. Menolak } \\
\text { penindas/ideologi } \\
\text { 2. Mengetahui bagaimana } \\
\text { kerja sistem: } \\
\text { a. Mengetahui sistem } \\
\text { sebagaimana } \\
\text { penyebab } \\
\text { b. Mengetahui } \\
\text { pertentangan antara } \\
\text { cara dan tujuan } \\
\text { c. Analisis makro } \\
\text { d. Menggeneralisasi } \\
\text { penindas sistem }\end{array}$ \\
\hline
\end{tabular}

\begin{tabular}{|c|c|c|c|}
\hline \multirow[t]{2}{*}{$\begin{array}{l}\text { III. AKSI } \\
\text { Apa yang bisa } \\
\text { Dilakukan untuk } \\
\text { Mengubah } \\
\text { keadaan? } \\
\text { Apa yang harus } \\
\text { dilakukan? } \\
\text { Apa yang Anda } \\
\text { lakukan? } \\
\text { Apa yang telah } \\
\text { dilakukan? }\end{array}$} & $\begin{array}{l}\text { 1. Fatalisme: } \\
\text { a. Melarikan diri } \\
\text { b. Menerima }\end{array}$ & $\begin{array}{l}\text { 1. Aktif bekerja sama } \\
\text { dengan penindas } \\
\text { (kolusi): } \\
\text { a. Meniru perilaku pea. } \\
\text { nindas (pakaian, } \\
\text { kebiasaan) } \\
\text { c. Agresi salah arah } \\
\text { (agresi horisontal, } \\
\text { intra- punitive) } \\
\text { d. Bersikap } \\
\text { paternalistik } \\
\text { terhadap sesama } \\
\text { e. Memenuhi } \\
\text { keinginan penindas }\end{array}$ & $\begin{array}{l}\text { 1. Aktualisasi Diri: } \\
\text { a. Mencari model peran } \\
\text { yang sesuai } \\
\text { b. Menghargai diri } \\
\text { c. Mengembangkan } \\
\text { diri/mencari } \\
\text { pengetahuan } \\
\text { d. Menjadi subyek/aksi } \\
\text { e. Percaya pada } \\
\text { sesama/belajar } \\
\text { bersama } \\
\text { f. Menerapkan solusi } \\
\text { baru } \\
\text { g. Mengandalkan } \\
\text { sumber daya } \\
\text { komunitas } \\
\text { h. Menentang } \\
\text { kelompok- kelompok } \\
\text { penindas }\end{array}$ \\
\hline & $\begin{array}{l}\text { 2. Menghidupi penindas } \\
\text { secara Pasif: } \\
\text { a. Menunggu kebaikan: } \\
\text { keberuntungan/patro } \\
\text { m } \\
\text { b. Bergantung pada } \\
\text { penindas }\end{array}$ & $\begin{array}{l}\text { 2. Bertahan: } \\
\text { a. Berkelompok } \\
\text { b. Membuat jaringan } \\
\text { kerja } \\
\text { c. Menjauhi penindas } \\
\text { d. Menentang individu } \\
\text { penindas } \\
\text { e. Mengubah keadaan }\end{array}$ & $\begin{array}{l}\text { 2. Mengubah Sistem: } \\
\text { a. Mengedepankan } \\
\text { dialog daripada } \\
\text { polemik } \\
\text { b. Kerjasama } \\
\text { c. Pendekatan ilmiah } \\
\text { d. Mengubah norma, } \\
\text { prosedur dan hukum }\end{array}$ \\
\hline
\end{tabular}




\section{Pembahasan}

Konsep postrealitas ini sepenuhnya mengacu pada kondisi realitas budaya yang virtual ataupun artifisial di dalam era komunikasi massa dan konsumsi massa. Realitas-realitas itu mengungkung "kita" dengan berbagai bentuk simulasi (penggambaran dengan peniruan). Simulasi itulah yang mencitrakan sebuah realitas yang pada hakikatnya tidak senyata realitas yang sesungguhnya.

Realitas ini tampil melalui media-media yang menjadi "kiblat" utama masyarakat massa. Melalui media realitas-realitas diskontruks dan ditampilkan dengan simulators, dan pada gilirannya menggugus menjadi gugusan-gugusan imaji yang "menuntun" manusia modern pada kesadaran yang ditampilkan oleh simulator-simulator tersebut, yang disebut gugusan simulacra. ${ }^{19}$

Pada lapis pemahaman ini ada keterkaitan erat antara modernitas dan kapitalisme. Pola-pola perilaku modernitas berjalan paralel dengan proses ekonomi-politik (produksi, distribusi, dan konsumsi) yang merupakan "ritual" ideologi kapitalisme.

Komoditas menciptakan strukturasi barang dan jasa dalam susunan hierarkis yang memberikan "imaji" dalam membentuk prestise sosial dan posisi seseorang dalam sistem tersebut. Misalnya mobil, dengan nilai tukar pada jenis masing-masing menunjukkan posisi orang yang terlibat dalam struktur itu. BMW, Mercy, Roll Royce, Royal Saloon, dan Volvo akan memberi prestise dan hierarki elit terhadap konsumennya, sementara Suzuki Carry 1000, Espass, Mitsubishi T120ss dan lain sebagainya

19 Simulakra adalah analisa Jean Baudrillard terhadap realitas-realitas bentukan yang sengaja dibentuk untuk menghegemoni dan mengarahkan masyarakat untuk menerimanya sebagai realitas yang sesungguhnya. Suatu ruang dimana realitas-realitas baru dicipta untuk menggiring massa pada suatu tatanan baru yang dibangun penguasa untuk memfasilitasi segala kepentingannya. Realitas ciptaan ini disulap sebagai medan grafitasi yang mampu menyedot perhatian massa untuk memperhatikan dan menirunya. Perlu diingat bahwa realitas simulakrum itu ada dalam media televisi ataupun media yang menggunakan teknologi canggih lainnya. Dalam media tersebut, tidak dikenal dikotomi antara yang tampak dengan yang rahasia. Segalanya disamakan saja, menjadi realitas simulakrum. Lihat, Selu Margaretha Kushendrawati, Hiperrealitas dan Ruang Publik: Sebuah Analisis Cultural Studies, (Jakarta: Penaku, 2011), hlm. 87-88. 
memberikan hierarki estetis "kelas rendah" bagi status sosial pengendaranya. Makna dan fungsi mobil sebagai alat transportasi dan kenyamanan berkendaraan berubah menjadi fungsi atributif dan prediktif bagi pemiliknya.

Pencitraan-pencitraan terhadap komoditas itu membawa konsekuensi logis terhadap pembentukan karakter masyarakat massa yang serba tergantung pada "komunikasi massa" melalui media massa. Dalam komunikasi massa semua informasi politik, sejarah, budaya, diterima dalam bentuk yang sama, sekaligus tidak penting dan menakjubkan dibandingkan dengan berita serba-serbi. Semua informasi diaktualkan, artinya dibuat dramatis dengan cara yang spektakuler . Tetapi yang paling benar adalah merasa di sana tanpa ada di sana, dengan kata lain fantasi. Apa yang diberikan komunikasi massa pada kita bukanlah realitas tetapi kebimbangan realitas. $^{20}$

Maka kebenaran media massa adalah berfungsi untuk menetralkan ciri khas nyata, unik, peristiwa dunia, untuk menggantikan dunia yang beragam dengan dunia yang homogen antara yang satu dengan yang lainnya seperti apa adanya, yang saling mengartikan satu sama lain dan yang mengirim kembali satu sama lain. ${ }^{21}$

Di dalam budaya massa itu, menunjukkan bagaimana proses transformasi nilai dari media ke dalam kesadaran masyarakat massa telah "memanjakan" kesadaran itu dalam "memperturutkan" keinginannya (desiré, "hawa nafsu") untuk mengikuti ritual-ritual ekonomi-konsumtif. Kondisi psikologis ini mengantarkan pada pemujaan (fetishisme) terhadap idola yang dipresentasikan oleh media. Pada saat yang sama budaya ini menjebak masyarakatnya pada "silent majorities". ${ }^{22}$ Masyarakat menerima begitu saja media massa, layaknya yakin bahwa setiap manusia harus bernafas setiap saat untuk dapat hidup atau layaknya menerima bahwa matahari pasti terbit dari timur dan terbenam di barat.

Perkembangan dunia posrealitas itu telah membentangkan sebuah persoalan filosofis mengenai eksistensi dan batas-batas

${ }^{20}$ Jean P Baudrillard, Masyarakat Konsumsi, terj. Wahyunto, (Yogyakarta: Kreasi Wacana, 2011), hlm. 17.

${ }^{21}$ Baudrillard, Masyarakat Konsumsi,,, hlm. 154.

${ }^{22}$ Selu Margaretha Kushendrawati, Heperrealitas..., hlm. 8. 
pengetahuan tentang apa yang disebut yang nyata itu. Posrealitas dapat dijelaskan sebagai sebuah kondisi matinya realitas, dalam pengertian diambil-alihnya posisi realitas itu oleh apa yang sebelumnya disebut sebagai nonrealitas (non-reality). Lewat kemampuan ilmu pengetahuan dan teknologi dalam menciptakan realitas artifisial, dunia posrealitas menawarkan berbagai pengalaman, penjelajahan dan panorama-panorama baru yang memesona, yang belum pernah dialami sebelumnya. ${ }^{23}$

Akan tetapi, dunia realitas artifial itu banyak pula merenggut apa yang sebelumnya disebut dunia realitas ilmiah, seperti kedekatan manusia dengan aura, keaslian, eksotisme alam, warisan-warisan luhur kebudayaan, serta kekuatan-kekuatan spiritual yang selama ini merupakan magnet dunia kehidupan. Maka, ketika realitas-realitas alamiah tersebut telah lenyap, dan diambil-alih oleh berbagai realitas yang artifisial, manusia lalu terkurung di dalam perangkap dunia artifisial, yaitu dunia yang serba permukaan, imanen dan dangkal serta tidak mampu lagi menemukan jalan kembali ke arah realitas alamiah, kekayaan kultural, dan kedalaman pengalaman transendental.

Perkembangan dunia posrealitas, dengan demikian, telah membentangkan berbagai pertanyaan filosofis yang harus dijawab, khususnya pertanyaan teologis dan akademis mengenai hendak dibawa ke manakah umat manusia lewat wahana realitas baru tersebut? Apakah pengalaman yang ditawarkan dunia posrealitas ini dapat memperkokoh eksistensi manusia, atau malah menghancurkannya? Apakah penjelajahan yang disediakannya dapat memperkaya pengetahuan manusia, atau malah memusnahkannya? Apakah panorama yang ditawarkannya dapat memperhalus budi dan daya spiritual manusia, atau malah merusaknya? Apakah dunia ini membawa manusia menuju kemajuan, atau malah kehancuran ${ }^{24}$ Lalu pendidikan seperti apa yang bisa memberikan gambaran sekaligus solusi dalam mengahadapi dunia posrealitas (posreality)?. Inilah beberapa pertanyaan filosofis yang mengemuka berkaitan dengan peralihan dari dunia realitas ke arah dunia posrealitas.

23 Yasraf Amir Pilian, Posrealitas (Realitas kebudayaan dalam era posmetafisika), (Yogyakarta: Jalasutra, 2004), hlm. 53-54.

${ }^{24}$ Pilian, Posrealitas ..., hlm. 54. 
Jika kita perhatikan secara saksama fakta sejarah yang telah terukir di atas, di mana, apa saja yang dahulu dianggap bernilai dan bermakna kini sudah mulai memudar dan menuju keruntuhan. Seperti yang di katakan Nietzche dalam metaforanya yang dikutip oleh St. Sunardi, tentang krisis kebudayaan (nihilisme):

Apa yang aku kisahkan adalah sejarah dua abad yang akan datang. Aku melukiskan apa yang akan terjadi, apa yang tak mungkin datang secara lain: kedatangan nihilisme. Sejarah nihilisme ini bahkan dapat dikisahkan dari saat sekarang karena kepastiannya sudah terlihat di saat ini. Masa depan dari nihilisme sudah berbicara pada saat sekarang ini dengan ratusan tanda-tanda; tanda-tanda akan datangnya nihilisme ini mencuat di mana-mana. Semua gendang telinga sekarang ini sudah digetarkan oleh musik masa depan itu .... Kebudayaan Eropa kita sedang bergerak menuju suatu malapetaka, dengan tekanan yang tercabik yang meningkat dari tahun ke tahun, dengan gerakan-gerakan penuh kegelisahan, kekerasan dan ... bagaikan aliran sungai yang sedang hendak mencapai lautan, yang tidak sanggup lagi merenungkan dirinya sendiri, yang takut merenungkan. ${ }^{25}$

Nietzche melukiskan bahwa gerak kebudayaan kita sedang menuju suatu malapetaka, dengan tekanan yang tercabik yang meningkat dari tahun ke tahun, dengan gerakan-gerakan penuh kegelisahan, kekerasan dan ... bagaikan aliran sungai yang sedang hendak mencapai lautan, yang tidak sanggup lagi merenungkan dirinya sendiri, yang takut merenungkan, ${ }^{26}$ maka, tanpa merendahkan atau mengecilkan arti dan peran paradigma pendidikan yang ada selama ini, maka, paradigma pendidikan kritislah yang paling tepat menurut peneliti untuk dijadikan kerangka acuan dalam mengurai bahkan idealnya mengantisipasi budaya posrealitas sekarang ini, sehingga bisa menciptakan ruang dan kesempatan agar masyarakat terlibat dalam suatu proses dialog "penciptaan struktur yang secara fundamental baru dan lebih baik atau lebih adil". ${ }^{27}$ Atau menurut istilah Gramsci sebagai proses counter hegemony. ${ }^{28}$

${ }^{25}$ St. Sunardi, Nietzche, (Yogyakarta: LkiS, 2011), hlm. 33

${ }^{26}$ Sunardi, Nietzch ..., hlm. 33.

27 Masour Faqih, Runtuhnya Teori Pembangunan dan globalisasi, (Yogyakarta: Insist Press, 2011), hlm. 33

${ }^{28}$ Faqih, Runtuhnya Teori.., hlm. 30. 
Pendidikan kritis (critical pedagogy) adalah mazhab pendidikan yang meyakini adanya muatan politik dalam semua aktivitas pendidikan. Pendidikan tidaklah berada dalam ruang dan massa yang steril, tetapi merupakan kegiatan politik menghadapi sistem dan struktur yang bersifat hegemoni. ${ }^{29}$ Pendidikan merupakan arena perjuangan politik. ${ }^{30}$ Ini artinya, pendidikan bukanlah suatu lembaga yang netral tetapi merupakan pelaksana dari sistem kekuasaan yang ada di masyarakat. ${ }^{31}$ Mazhab ini tidak merepresentasikan satu gagasan yang tunggal dan homogen. Namun, para pendukung mazhab ini disatukan dalam satu tujuan yang sama yaitu memberdayakan kaum tertindas dan mentransformasikan ketidakadilan sosial yang terjadi di masyarakat melalui pendidikan. Pertanyaan-pertanyaan pokok yang diajukan mazhab ini adalah: apakah pendidikan mengandung muatan language of critique? Apakah pendidikan mengandung muatan language of possibility? Apakah pendidikan telah memberi ruang bagi berkembangnya agensi sebagai proses pembentukan critical subjectifity? ${ }^{32}$

Visi pendidikan kritis didasarkan pada suatu pemahaman bahwa pendidikan tidak bisa dipisahkan dari konteks sosial, kultural, ekonomi, politik yang lebih luas. ${ }^{33}$ Institusi pendidikan tidaklah netral, independen dan bebas dari berbagai kepentingan, tapi justru menjadi bagian dari institusi sosial lain yang menjadi

${ }^{29}$ Faqih, Runtuhnya Teori.., hlm. 8.

${ }^{30}$ Dominasi menandakan adanya penyakit pada cinta: sadisme pada pihak penguasa serta masokisme pada pihak yang dikuasai. Karena cinta merupakan sebuah laku keberanian, bukan ketakutan, maka cinta adalah pemihakan pada orang lain. Tidak peduli di manapun kaum tertindas ditemukan, maka laku mencintai adalah pemihakan pada perjuangan mereka - perjuangan bagi pembebasan. ... lihat, Paulo Freire, Pendidikan Kaum Tertindas, terj. Mansour Fakih, Roem Topatimasang Dkk. (Jakarta: LP3ES, 2000), hlm. 75. Lihat juga, Mansour Faqih, "Pengantar Ideologi-Ideologi Pendidikan”, Ideologi-Ideologi Pendidikan karya William F. O’Neil:, (Yogyakarta: Pustaka Pelajar, 2002), hlm. Evi.

${ }^{31}$ H.A.R. Tilaar, Kekuasaan dan Pendidikan: Manajemen Pendidikan Nasional dalam Pusaran Kekuasaan, (Jakarta: Rineka Cipta, 2009), hlm. 115.

${ }^{32}$ M. Agus Nuryatno, Mazhab Pendidikan Kritis; Menyingkap Relasi Pengetahuan, Politik dan Kekuasaan, (Yogyakarta: Resist Book, 2008), hlm. $1-2$.

${ }^{33}$ Nuryatno, Mazhab Pendidikan.., hlm. 2. 
ajang pertarungan kepentingan. ${ }^{34}$ Pendidikan harus dipahami dalam kerangka relasi-relasi antara pengetahuan, kekuasaan dan ideologi. Ilmu pengetahuan bukanlah bebas nilai tetapi merupakan rekonstruksi dalam suatu masyarakat. Sistem kekuasaan dalam masyarakat menurut Foucault menghasilkan rekonstruksi ilmu pengetahuan yang terkait kepada kepentingan dari kelompok yang berkuasa. Bukan hanya ilmu pengetahuan tetapi juga di dalam berbagai hubungan masyarakat termasuk masalah-masalah seksual juga dipengaruhi oleh sistem kekuasaan tersebut. ${ }^{35}$

Apa yang dimaksud dengan critical thinking / consciousness di sini adalah mode of thought yang mampu menyingkap makna fenomena-fenomena posrealitas atau asumsi-asumsi yang hanya berdasar "comman sense". ${ }^{36}$ Akan tetapi harus diingat bahwa mengembangkan critical consciousness tidak bisa dengan cara didepositokan atau diimpose dari luar, tetapi harus dilahirkan lewat usaha yang kreatif dari dalam peserta didik sendiri. Kesadaran kritis tidak dapat dicangkokkan, tapi dibangun lewat kesadaran diri peserta didik. Menurut Robert Pepperell; Kesadaran tidak terbatas secara eksklusif pada otak. Kesadaran merupakan fungsi dari organisme, bukan organ. Kesadaran hanya bisa dilihat sebagai sifat yang muncul. Dalam hal ini seperti mendidih: menimbang panas, gaya berat dan tekanan udara yang memadai, air dalam sebuah ketel akan memulai mendidih. Kita bisa melihat apa yang sedang mendidih, kita bisa memandangnya sebagai sesuatu untuk kita beri nama, kita tidak menilainya misterius, tetapi kita tidak bisa memisahkannya dari kondisi-kondisi yang menghasilkannya. Demikian juga kesadaran adalah sifat yang muncul dari serangkaian kondisi yang ada. ${ }^{37}$

Sementara itu Mudji Sutrisno, mendefinisikan kesadaran adalah pertimbangan budi yang semakin bijak atau sering disebut

${ }^{34}$ Nurani Soyomukti, Teori-Teori Pendidikan; Tradisional, (Neo) Liberal, Marxis-Sosialis, Posmodern, (Jogjakarta: Ar-Ruzz Media, 2010), hlm. 483

${ }^{35}$ H.A.R. Tilaar Dkk, Pedagogik Kritis: Perkembangan, Substansi, dan Perkembangannya di Indonesia, (Jakarta: Rineka Cipta, 2011), hlm. 21

${ }^{36}$ Dalam istilah Paulo Freire, penyadaran diartikan sebagai belajar memahami kontradiksi sosial, politik dan ekonomi, serta mengambil tindakan untuk melawan unsur-unsur yang menindas dari realitas tersebut. Lihat, Paulo Freire, Pendidikan..., hlm. 1

${ }^{37}$ Robert Pepperel, Posthuman; Kompleksitas Kesadaran, Manusia dan Teknologi, (Yogyakarta: Kreasi Wacana, 2009), hlm. 314. 
dimensi rasional manusia. Ketika nafsu atau naluri menggelora, manusia tidak hanya menuruti atau langsung menanggapinya. Ia mampu menimbangnya untuk dipenuhi atau ditunda. Bahkan, tidak dipenuhi sama sekali karena tidak pantas sebagai manusia. Dalam pertimbangan dengan kesadaran akal budi, orang akan sampai pada sebuah puncak humanisasi yang mana ia tidak hanya menera hidup berdasar enak-tidak enak, nafsu senang atau benci, untung atau rugi, adil atau tidak adil. Peneraannya akan berpangkal pada keutuhan kemartabatan manusia sebagai manusia. Dimensi inilah yang kemudian dikenal sebagai dimensi kesadaran nurani. Maksudnya, peneraan hidup actus vivens: sikap dan penghayatan terhadap hidup yang disumberkan pada keseluruhan pertimbangan rasional, rasa dan intuisi si manusia dalam keutuhannya. ${ }^{38}$

Mazhab pendidikan kritis berbasis pada keadilan dan kesetaraan. Oleh karena itu, pendidikan tidak hanya berkutat pada pertanyaan seputar sekolah, kurikulum, dan kebijakan pendidikan, tetapi juga tentang keadilan sosial dan kesetaraan. Dalam konteks dunia posrealitas, pendidikan kritis juga harus mempertanyakan tanda, image citra dan makna yang dibangun oleh budaya posrealitas untuk mencari jalan pemecahannya. ${ }^{39}$ Keadilan merupakan kebajikan utama. Sedemikian utamanya sehingga dalam keadilan terkandung semua kebajikan, demikian Plato. Sementara itu menurut Aristoteles, seperti dikutip John Rawls, keadilan merupakan kebajikan yang lengkap dalam arti seutuhnya karena keadilan bukanlah nilai yang harus dimiliki dan berhenti pada taraf pemiliknya bagi diri sendiri, melainkan juga merupakan "pelaksanaan aktif", dalam arti harus diwujudkan dalam relasi dengan orang lain. Dalam keadilan sebagai fairness, posisi kesetaraan asali berkaitan dengan kondisi alam dalam teori tradisional kontrak sosial. Posisi asali ini tentu tidak dianggap sebagai kondisi historis, apalagi sebagai kondisi primitif kebudayaan. Ia dipahami sebagai situasi hipotetis yang dicirikan mengarah pada konsepsi keadilan tertentu. Salah satu bentuk keadilan sebagai fairness adalah memandang berbagai pihak dalam situasi awal sebagai rasional dan sama-sama netral. Teori

${ }^{38}$ Mudji Sutrisno, "Identitias Budaya Manusia Indonesia", Teori-Teori Kebudayaan,(Yogyakarta: Kanisius, 2005), hlm. 356-357.

${ }^{39}$ H.A.R. Tilaar Dkk, Pedagogik Kritis: Perkembangan, Substansi, dan Perkembangannya di Indonesia, (Jakarta: Rineka Cipta, 2011), hlm. 6. 
keadilan adalah bagian, barangkali bagian paling signifikan, dari teori pilihan rasional. ${ }^{40}$

Proses pembelajaran pun adalah proses pembelajaran yang aktif, tidak berkutat pada apa yang disampaikan oleh seorang guru, siswa diarahkan untuk menjadi manusia purna yang memiliki tingkat kemampuan yang tinggi dan mampu berpikir kritis (mampu membaca gerak zaman/posrealitas). ${ }^{41}$ Dalam pendidikan kritis, pembelajaran ditekankan pada bagaimana memahami, mengkritik, memproduksi, dan menggunakan ilmu pengetahuan sebagai alat untuk memahami realitas hidup dan mengubahnya. ${ }^{42}$ Dari perspektif mazhab ini, sekolah diyakini memainkan peranan yang signifikan dalam membentuk kehidupan politik dan kultural. Sedangkan guru tidak dianggap sebagai pusat segalanya.

Isi atau materi pelajaran dalam pendidikan kritis bukan semata hak prerogatif para ahli tanpa melibatkan peserta didik. Dalam istilah Paulo Freire, hubungan guru-murid bukan lagi guru-nyamurid dan murid-nya-guru, tetapi guru-yang-murid dan muridyang-guru. Guru tidak lagi menjadi orang-yang-mengajar, tetapi orang yang mengajar dirinya melalui dialog dengan para murid, yang pada gilirannya di samping diajar mereka juga mengajar. ${ }^{43}$ Guru juga harus menjadi pendidik transformatif, agar menyadari adanya muatan, konsekuensi, dan kualitas politik dalam semua aktivitas pendidikan dan pengajaran. Karakteristik pendidik transformatif di antaranya : (a).memandang sukses akademik tidak hanya diukur oleh indikator kesuksesan kerja. (b).menempatkan pendidikan sebagai media mobilitas sosial. (c).memandang peserta didik sebagai historical beings, yaitu makhluk praksis yang hidup secara otentik hanya jika terlibat dalam transformasi dunia. ${ }^{44}$ (d).meyakini kemampuan peserta didik untuk berpartisipasi dalam penciptaan sejarah manusia. (e).senantiasa menghadapkan teksteks normatif yang tertuang dalam kurikulum dengan realitas sosial yang terjadi di luar kelas. (f).memandang perlu

40 John Rawls, Teori Keadilan: Dasar-Dasar Filsafat Politik untuk Mewujudkan Kesejahteraan Sosial dalam Negara, (Yogyakarta: Pustaka Pelajar, 2006), hlm. 13-18.

${ }_{41}$ Lihat, http://teknoq.wordpress.com/tag/mazhab-pendidikan-kritis/, diakses: Senin, 30 Januari 2012, jam: 11.55 WIB.

${ }^{42}$ Nuryatno, Mazhab pendidikan..., hlm.6.

${ }^{43}$ Freire, Pendidikan..., hlm. 62.

${ }^{44}$ Freire, Pendidikan..., hlm. 62. 
dikembangkannya language of critic dan language of possibility dalam pendidikan. ${ }^{45}$

Pendekatan bottom up dipilih untuk mengonstruksi kurikulum yang menjadikan peserta didik sebagai titik pijak atau entry point. Proses pembelajaran dalam pendidikan kritis ditekankan pada how to think daripada what to think (pos realitas). Karena dalam proses itulah akan terjadi kritisisme, sharing ideas, saling menghargai dan assesment terhadap pengetahuan. Penekanan aspek how to think akan bisa terlaksana jika dalam pembelajarannya menggunakan metode dialogis, bukan cerita, yang steril tanpa tujuan konsensus sehingga terjadi proses perbandingan dan refleksi yang membuat siswa berfikir kritis. ${ }^{46}$

Filasafat dasar pendidikan kritis berdasar pada asumsi bahwa : (a) Manusia punya kapasitas berkembang dan berubah karena punya potensi belajar. (b) Manusia punya panggilan ontologis dan historis untuk menjadi makhluk sempurna. (c) Manusia adalah makhluk praksis yang hidup secara otentik hanya jika terlibat dalam transformasi dunia. ${ }^{47}$

Mazhab pendidikan kritis sejatinya menjadi alat untuk membedah realitas sosial yang bisa diintrodusir dalam ranah lembaga pendidikan dan realitas lain (dunia posrealitas). Ide-ide teknis dalam mazhab ini sangat baik dalam melahirkan nalar kritik sehingga pada gilirannya ada harapan bahwa peserta didik akan memiliki kepekaan zaman.

Berdasarkan penelitian yang dilakukan, maka temuan yang dihasilkan adalah sebagai berikut: Jika dianalisis lebih jauh latar belakang dari berkembangnya dunia posrealitas adalah akibat dari kemajuan ilmu pengetahuan dan teknologi komunikasi. Bahwa perkembangan ilmu pengetahuan dan teknologi komunikasi adalah sesuatu yang menggembirakan itu sudah pasti. Namun perkembangan ini rupanya tidak lepas dari cacat yang melekat padanya. Di dalam teori-teori sosial kritis, teknologi telah lama dituduh sebagai penyebab dari berbagai penyakit sosial, seperti totalitarianisme di tataran ide (fakta yang menjajah kreativitas), pencipta lapangan kerja yang tidak membutuhkan kreativitas, dan

45 Lihat, http://miftasmart-key.blogspot.com/2011/04/mazhabpendidikan-kritis.html, diakses: Senin, 30 Januari 2012, jam: 12.04 WIB.

${ }^{46}$ Nuryatno, Mazhab pendidikan ..., hlm. 7-9.

${ }^{47}$ Nuryatno, Mazhab pendidikan ..., hlm. 10. 
pencipta masyarakat konsumeris yang hedonis. Teknologi memudahkan hidup manusia, dan itu membuatnya menjadi manja. Kemanjaan adalah sumber dari banyak penyakit sosial di masyarakat sekarang ini. Teknologi membuat manusia menjadi miskin imajinasi. Ia dipenjara oleh teknikalitas yang kering seolah tanpa jiwa. Nilai-nilai kemanusiaan yang bermakna lenyap ditelan kalkulasi rasional teknis matematis.

\section{Kesimpulan}

Perkembangan teknologi memang telah banyak mengubah hidup manusia itu sudah menjadi fakta sejarah, namun korban yang dihasilkan juga sangat mengerikan, seperti yang dapat kita lihat pada melemahnya mental manusia modern, pragmatisme dangkal yang menghalalkan segala cara untuk mencapai hasil, dan eksperimen dengan menggunakan manusia sebagai kelinci percobaan.

Dalam konteks paradigma pendidikan kritis setiap bentuk teknologi, termasuk teknologi komunikasi, haruslah menjadi instrumen pembebasan, dan bukan penindasan yang membuat manusia menderita. Teknologi harus mengabdi pada cita-cita mendasar demokrasi, yakni memungkinkan setiap individu untuk memperoleh kebebasan personal secukupnya, dan berpartisipasi secara aktif di dalam berbagai aktivitas yang terkait dengan kepentingan publik.

Dewasa ini, pilihan-pilihan yang dibuat manusia, sebagai konsekuensi dari kebebasan individu yang kian berkembang, dimediasi oleh teknologi. Maka orang yang sungguh bebas adalah orang yang melek pada kecanggihan teknologi, terutama teknologi komunikasi. Teknologi tidak pernah netral dan obyektif murni, melainkan selalu terkait dengan dampak dan kepentingan politis tertentu. Sebaliknya bagi mereka yang buta teknologi, pilihan menjadi sangat terbatas. Inilah karakter otoriter dari teknologi, bahwa dia bersikap diskriminatif kepada mereka yang tidak bisa mengaksesnya.

Dalam perjalanannya kemajuan ilmu pengetahuan dan teknologi informasi dan komunikasi tidak sertamerta membawa manusia kepada kondisi yang berkesadaran kritis seperti yang diidealkan oleh Freire. Alih-alih membawa kepada kesadaran kritis yang terjadi adalah kemajuan ilmu pengetahuan dan teknologi 
komunikasi telah membawa manusia kepada kesadaran yang artifisial atau kesadaran yang tidak sebenarnya.

Di sinilah signifikansi paradigma pendidikan kritis dalam usaha untuk mengemansipasi manusia yang kesadarannya telah terserap oleh posrealitas. Bahwa apa yang terjadi di dalam dunia posrealitas adalah akibat terdegradasinya fakultas kritis manusia, akan tetapi jika fakultas kritis manusia masih terjaga dengan baik maka dunia posrealitas tidak akan berdampak apa-apa terhadap manusia.

\section{Kepustakaan}

Arikunto, Suharsimi. 2005. Manajemen Penelitian. Jakarta: Rineka Cipta.

Bakker, Anton dan Ahmad Charis Zubair. 1990. Metodologi Penulisan Filsafat. Yogyakarta: Kanisius.

Baudrillan. 2011. Masyarakat Konsumsi, terj. Wahyunto. Yogyakarta: Kreasi Wacana.

Baudrillard, Jean. 1994. The Illusion of the End. London: Polity Press.

Danesi, Marcel. 2011. Pesan, Tanda dan Makna Buku Teks Dasar Mengenai Semiotika dan Teori Komunikasi. terj. Evi Setyarini dan lusi Lian Piantari. Yogyakarta: Jalasutra.Faqih, Masour. 2011. Runtuhnya Teori Pembangunan dan globalisasi. Yogyakarta: Insist Press.

Freire, Paulo. 2009. Menggugat Pendidikan fundamentalisme, Konservatif, liberal, Anarkis: Pendidikan yang Membebaskan, Pendidikan yang Memanusiakan. Yogyakarta: Pustaka Pelajar.

H.A.R. Tilaar Dkk. 2011. Pedagogik Kritis: Perkembangan, Substansi, dan Perkembangannya di Indonesia. Jakarta: Rineka Cipta.

H.A.R. Tilaar. 2009. Kekuasaan dan Pendidikan: Manajemen Pendidikan Nasional dalam Pusaran Kekuasaan. Jakarta: Rineka Cipta.

------, 2012. Perubahan Sosial dan Pendidikan: Pengantar Pedagogik Transformatif untuk Indonesia. Jakarta: Rineka Cipta. 
Kartono, Kartini. 1990. Pengantar Metodologi Riset Sosial. Bandung: Mandar Maju

Nuryatno, M. Agus. 2008. Mazhab Pendidikan Kritis; Menyingkap Relasi Pengetahuan, Politik dan Kekuasaan. Yogyakarta: Resist Book

Oxford Advanced Leaner's Dictionary. New York: Oxford University Press.

Pepperel, Robert. 2009. Posthuman; Kompleksitas Kesadaran, Manusia dan Teknologi. Yogyakarta: Kreasi Wacana.

Pilian, Yasraf Amir. 2004. Posrealitas (Realitas kebudayaan dalam era posmetafisika). Yogyakarta: Jalasutra.

------, 1998. Sebuah Dunia yang Dilipat: Realitas Kebudayaan Menjelang Milinium Ketiga dan Matinya Posmodernisme. Bandung: Mizan.

Prayogo, Imam. 2003. Metodologi Penelitian Sosial dan Agama. Bandung: Rosda Karya.

Rawls, John. 2006. Teori Keadilan: Dasar-Dasar Filsafat Politik untuk Mewujudkan Kesejahteraan Sosial dalam Negara. Yogyakarta: Pustaka Pelajar.

Reality. 1995. The quality of being real or of resembling sth that is real: the lifelike reality of his paintings. Lihat, A S Hornby.

Sianipar, Gading J. 2005. Tubuh dan Kesadaran dalam Budaya Imajinasi: Penafsiran atas Budaya Masyarakat yang Diserbu Oleh Teknologi dan Media Komunikasi, Teori-Teori Kebudayaan. Yogyakarta: Kanisius.

Smith, William A. 2008. Conscientizacao Tujuan Pendidikan Paulo Freire. Yogyakarta: Pustaka Pelajar.

Soyomukti, Nurani. 2010. Teori-Teori Pendidikan; Tradisional, (Neo) Lib-eral, Marxis-Sosialis, Posmodern. Jogjakarta: ArRuzz Me-dia.

St. Sunardi. 2011. Nietzche. Yogyakarta: LkiS.

Sugiono. 2006. Metode Penelitian Pendidikan; Pendekatan Kuantitatif, Kualitatif dan RD. Bandung: Alfabeta.

Sutrisno, Mudji \& Hendar Purwanto. 2005. Teori-Teori Kebudayaan. Yogyakarta: Kanisius.

------, 2005. Identitias Budaya Manusia Indonesia, Teori-Teori Kebudayaan. Yogyakarta: Kanisius. 
